\title{
LEARNING BY INTERNATIONALIZATION: POSITIVE EFFECTS ON INNOVATION IN CHINESE COMPANIES
}

\author{
Nikola Zivlak, Marko Ljubičić, Ming Xu, Jelena Demko-Rihter, Bojan Lalić
}

Original scientific paper

The purpose of this research is to analyse the relationship between innovation and internationalization in Chinese companies and to test presented research model. During the research process, 486 companies from China were analyzed and all four types, product, process, marketing and organizational innovations are proved to be positively influenced by internationalization. In addition to this, it is proved that for improvement of marketing and organizational innovation high-level of internationalization is highly recommended. What is more, this research has proved that direct contact with foreign customers is extremely important for having higher benefits of internationalization in the context of improvement of all four types of innovation.

Keywords: Chinese company; Chinese market; innovation; internationalization

Učenje internacionalizacijom: pozitivni efekti na inovacije u kineskim kompanijama

Izvorni znanstveni članak

Svrha ovog istraživanja je analiza odnosa između inovacija i internacionalizacije, kao i testiranje prezentiranog modela istraživanja. Istraživanjem je obuhvaćeno 486 kompanija iz Kine i dokazano je da internacionalizacija pozitivno utječe na sva četiri tipa inovacija, i to proizvoda, procesa, marketinga i organizacije. Također je dokazano i da se za postizanje inovacija u području marketinga i organizacije naročito preporučuje tzv. internacionalizacija visoke razine. Istraživanje je također dokazalo da je direktni kontakt sa stranim kupcima od iznimnog značaja za ostvarivanje većih koristi od internacionalizacije u kontekstu unapređenja sva četiri tipa inovacija.

Ključne riječi: inovacije; internacionalizacija; kineska kompanija; kinesko tržište

\section{Introduction}

In the previous decade, innovation has been a hot topic for academics and governments from all around the world. It is now widely believed that innovation is one of the key factors for economic development and generally for maintaining competitiveness in today's business environment that seems to be more complex than ever before. China, the second largest economy in the world, and its government especially place emphasis on innovation that should enable restructuring of its industry and long term sustainability of its economy. However, many people in China and abroad do not analyze this phenomenon very deeply and do not possess enough knowledge about the innovation in China. It is very evident that most of the foreigners are not totally convinced about the innovation efforts in Chinese companies and the current stage of their development.

China is the country that has seen enormous speed of change in almost every aspect, from everyday life to business, which implies this is simply a perfectly suitable place for conducting research about innovation, especially connected with Chinese companies that are developing faster than in any other place in the world and that have pretensions to establish much more serious positions on the global market than they have at the moment. What is more, this research should provide a unique approach to analyzing the relationship between innovation in Chinese companies and their internationalization.

\section{Theoretical background}

\subsection{Innovation}

Innovation is the core concept of a modern business and management studies. The goal of innovation is usually a positive change, to make someone or something better.

According to Porter [1], innovation is "a new way of doing things that is commercialized. The process of innovation cannot be separated from a firm's strategic and competitive context". Afuah [2] argues that innovation is the use of new technological and market knowledge to offer a new product or service that customer will want and that "the product is new in that its cost is lower, its attributes are improved, it now has attributes it never had before, or it never existed in that market before". As it was defined in the Oslo Manual [3] an innovation is the implementation of a new or significantly improved product (good or service), or process, a new marketing method, or a new organizational method in business practices, workplace organization or external relations. By definition from the Oslo Manual, all innovations must contain a degree of novelty. Three concepts for the novelty of innovations are accepted: new to the firm, new to the market and new to the world.

The goal of innovation is usually a positive change, to make someone or something better. Innovation leading to increased productivity is the fundamental source of increasing wealth in an economy. In economic terms innovation must increase value for producer and/or for customer.

Another classification of innovation is also offered by the Oslo Manual [3] and according to this manual there are four types of innovation defined: product, process, organizational and marketing innovation. Product innovation is defined as "the introduction of a good or service that is new or significantly improved with respect to its characteristics or intended uses"; process innovation as "the implementation of a new or significantly improved production or delivery method"; marketing innovation as "the implementation of a new marketing method 
involving significant changes in product design or packaging, product placement, product promotion or pricing"; and organizational innovation as "the implementation of a new organizational method in the firm's business practices, workplace organization or external relations".

Recent classification provided by Yip and McKern [4] even suggests nine types of innovation: technological, product, process, application, cost, value, supply chain, business model and non-consumer innovation.

\subsubsection{Innovations in China}

At the beginning of the second decade of XXI century, with already 30 years of constant growth of Chinese industry, it is obvious that innovation within Chinese enterprises is one of the most important and at the same times the most critical parameters. Historically, China is considered as an exceptionally innovative country. According to Temple [5] more than half of the basic inventions and discoveries people nowadays recognize and use in everyday life come from China. A lot of these inventions people today take for granted, without knowing that they actually originated in this Far Eastern country.

Tan [6] introduced a new term in the context of innovation in China - Chinnovation. According to this author, Chinnovation is "applying changes in technology and business strategy to have new and better ways to create value for both the customer and the corporation" and it is often characterized by eight distinctive characteristics: revenue, rapidity, requirements, reproduction, rivals, restrictions, remixing and raw materials

China is definitely the leading emerging market in the world and according to Govindarajan and Trimble [7] there are usually five gaps in the emerging markets in comparison to the developed countries and all five of them might become a great chance for innovation. These five gaps are: performance gap, infrastructure gap, sustainability gap, regulatory gap and preferences gap.

Williamson and Yin [8] indicate that emerging Chinese multinationals are adoption of different innovation models and leveraging innovation capabilities in order to create sustainable competitive advantage in the global market. Authors suggested that innovation in Chinese multinationals cover cost innovation, application and business model innovation, as well as technological one. Work presented by Wagner et al. [9] in 2014 BCG Innovation survey proves that Chinese companies are especially focused on innovation and are seeking to create an innovation-supportive environment. Yip and McKern [4] suggest that China has attractive characteristics which stimulate innovation, even though this market poses certain difficulties for multinational companies.

\subsection{Internationalization}

In international business and trade research, internationalization is one of the main subjects. Internationalization is generally viewed as a process of increasing involvement of companies in international markets. Internationalization can be broadly defined as "expanding across country borders into geographic locations that are new to the firm" [10].

One of the most famous internationalization theories, product life cycle theory, developed by Vernon [39], explains that the starting point for the internationalization process is typically an innovation that a company creates in its home country, which is often an advanced economy with population that has relatively higher income levels. Johanson and Vahlne [11, 12] suggested The Uppsala internationalization model which explains the process where enterprises gradually increase their international involvement.

Linden theory in international trade is also known as the theory of demand preference [13]. Linden theory argues that trade in manufactured goods was dictated not by cost concerns but rather by the similarity in the product demand across countries. According to this theory, the more intensive trade will exist between countries of the same income or industrial level and that a large part of international trade would consist of the exchange of similar or slightly different goods.

Tsai and Eisingerich [14] researched internalization strategies of emerging markets and concluded that otherwise firms that compete in the most advanced markets and possess strong technological know-how and financial resources, firms that are less competitive should better choose strategy that allows them to pursue lesscompetitive markets at the initial stage of internationalization.

Research of internationalization strategies of rapidly internationalizing high tech firms conducted by Crick, D. and Crick, J. [15] emphasized that firms with different speed (number of years) of internationalizing, scale (percentage of international business within the overall turnover) and scope (diversity of markets served) of operations are likely to strategize in various ways and it has to be considered both initial and subsequent

Inzelt [16] noticed that various firms have different routes to internationalization and there is no single model of internationalization that fits to all.

\subsubsection{Internationalization of Chinese companies}

Most of the traditional motivations and internationalization theories presented above are primarily based on the research done in the Western enterprises, especially large ones. In contrast to everything previously explained, Chinese companies face a very specific situation when they are internationalizing their businesses outside of China, since this country has the largest domestic market in the world.

On the other hand, Peng [17] and Mathews [18] have argued that the situation in today's China and Chinese companies' internationalization does not require theories that are specific for themselves and that would differ substantially from mainstream, primarily Western theories. It was estimated that Chinese companies will create a few million jobs overseas between 2010 and 2020. In 2010, number of employees working at Chinese companies outside of China was 780000.

According to World Trade Organization (WTO) China overtook Japan as the leading Asian exporter in 2004, three years after becoming WTO member. China 
surpassed the USA in 2007 and Germany in 2009 and become the world's largest exporter [38].

According to Kumar et al. [20] reasons behind internationalization of companies from emerging markets are the same reasons why companies in developed economies have gone and still are going international. Besides all the traditional motivators for internationalization, Li and Zhou's [21] research reveals that due to the existence of a lot similar firms in the industry of home country, Chinese Born Global companies decide to export directly to avoid fierce competition in the domestic market.

Backaler [22] suggests that large multinational companies are currently becoming aware of the strong competition entering the global stage directly from China. Same author also suggests that Chinese companies are internationalizing their business both for governmentdriven and business driven motivators. For Chinese companies, there is no market which is less important than the other one, and there is usually no too special or customized product which Chinese companies are not willing to put some effort to develop and to make their customers satisfied [23].

\subsection{Relationship between innovation and internationalization}

Both innovation and internationalization are terms that are recently widely used in the literature, especially in the context of China. By just simple observation of these two processes in the business world, it is possible to conclude that there is a certain connection between innovation and internationalization. While on one hand a lot of people personally have a strong sense that both of them are strongly interrelated and connected, on the other hand relatively few researches were done to analyze the relationship and mutual causation between innovation and internationalization.

Caves [24] was one of the first to argue that companies that expanded to other markets enjoyed higher returns to innovation. Kotabe [25] suggested that companies that are doing business internationally can improve their innovative capacity by being able to better utilize the wide range of resources available globally, that are often even not available at domestic firms. Hitt et al. [26] also said that companies can promote innovation by using the specific advantages of different countries. Zahra et al. [27] claimed that by exposing to various technological and regulatory environments in the process of their internationalization, companies in general enhance their competitive position and improve their innovative capabilities.

One line of research between innovation and internationalization are the ones that clearly show the positive relationship. At the same time, some of the researches evidently show that this relationship is very weak, or even that innovation does not stimulate internationalization and vice versa. Generally, a lot of literature shows that there is a positive relationship between innovation and internationalization.

Filipescu [28] clearly showed that there is a cyclical relationship between innovation and internationalization within Spanish companies. Kafouros et al. [29] also concluded that highly internationalized firms can improve their ability to innovate by having greater opportunities to learn.

Cassiman and Golovko [30] concluded that successful product innovation leads to the decision of small and medium enterprises to enter the export market.

According to Inzelt [16] internationalization boosts the international transfer of knowledge and international competition forces enterprises to be innovative, while the availability of new markets enforces them to implement innovations striving to increase their profits.

One researcher that represents this second line is Wakelin [31], who also analyzed differences between innovating and non-innovating companies in the context of internationalization. She analyzed the role of innovation in determining export behavior in the UK companies. The results of this study clearly showed that non-innovative firms are found to be more likely to export than innovative firms of the same size. Innovative companies in the UK seem to be more interested to use their innovation to exploit the domestic (in this case UK) market than to expand their business outside their national borders.

Molero [32] conducted research in the cases of Italy and Spain and according to this paper the international presence of non-innovative companies suggests that there is a relatively weak connection between processes of innovation and internationalization.

\section{Research methodology}

This research is based on previously presented intellectual problems and it should reveal the relationship between innovation and internationalization in Chinese companies.

Traditionally, patents and innovation surveys are two most important ways to measure innovation. Pavitt [33], Archibugi and Piant [34] and Smith [35] all argued that as a measure of innovation patent applications also have numerous disadvantages, since data about patent application is not absolutely relevant in the context of innovation. Contrary to this, innovation survey is a method that can acquire more specific information and details on innovative activities.

Taking into account all the specifications of this research, a questionnaire was developed and data collected directly from Chinese companies. Questionnaire (both in English and Chinese) was designed and structured in order to achieve the internal validity and reliability of the collected data. The term "innovation" used for the purpose of this research is the one according to the "Oslo Manual" created by the OECD. Received data were processed using SPSS tools Pearson chi-square test in order to uncover if there are significant similarities and differences among respondents for noninternationalized and internationalized innovative Chinese-owned companies.

Questionnaires were handed out to MBA and EMBA students at Donghua University's Glorious Sun School of Business and Management during the period from December 2012 to February 2013. During the same period of time, internet-mediated questionnaires were distributed via the internal data base of two organizations: 
China Council for the Promotion of International Trade (Shanghai Pudong Sub-council), and Shanghai Association of Export Commodities Enterprises. The total number of participants in this research is 486, where 298 companies were Chinese owned companies.

Construct validity of the questionnaire for measuring innovation was confirmed by principal components analysis. The first component comprises 50,174\% of overall variances, which indicates the homogeneity of the subscales, and that there is one object of measurement. All the items have high component loadings confirming that they have unique object of measuring and that this is the scale of innovation. Reliability of the scale was high (Cronbach's alpha $=0,869)$.

\subsection{Research model}

The main idea for this research model came from the Uppsala internationalization model developed by Johanson and Vahlne [11, 12] and the model developed by Filipescu [28].

In this research model, there are five different stages of internationalization considered: export through the agent, direct export, representative office, joint-venture and subsidiary. Due to the specific character of this research, these stages are divided according to different level of commitment these companies put into internationalization and to different types of knowledge accessible by a certain stage. Low-level internationalization (which means less commitment to internationalization) only brings the product knowledge to the Chinese company, while on the other side high-level internationalization (more commitment to internationalization) allows Chinese company to gain access to both product and market knowledge. Low-level internationalization includes export through the agent and direct export to overseas markets, and high-level internationalization includes representative office, jointventure and subsidiary of Chinese company in a foreign market.

However, there was still one dilemma concerning direct export to overseas markets, since this internationalization model could be considered as lowlevel internationalization stage in comparison to other internationalization models, but companies using this model can possibly gain access to both types of knowledge

The term "innovation" used for the purpose of this research model is classified according to the "Oslo Manual" created by the OECD. This manual offers definitions of each kind of innovation activity. According to this manual there are four types of innovation defined: product, process, organizational and marketing innovation. Three concepts for the novelty of innovations are accepted: new to the firm, new to the market and new to the world.

Research model specially designed for this research is presented in Fig. 1. The purpose of this model is to present the circular relationship between innovation and internationalization in Chinese companies. Thanks to the innovation activities (product, process, marketing or organizational innovation) existing in company, this enhances its strategic competences (assets, resources, technologies) and the company decides to internationalize its business outside of Chinese borders.

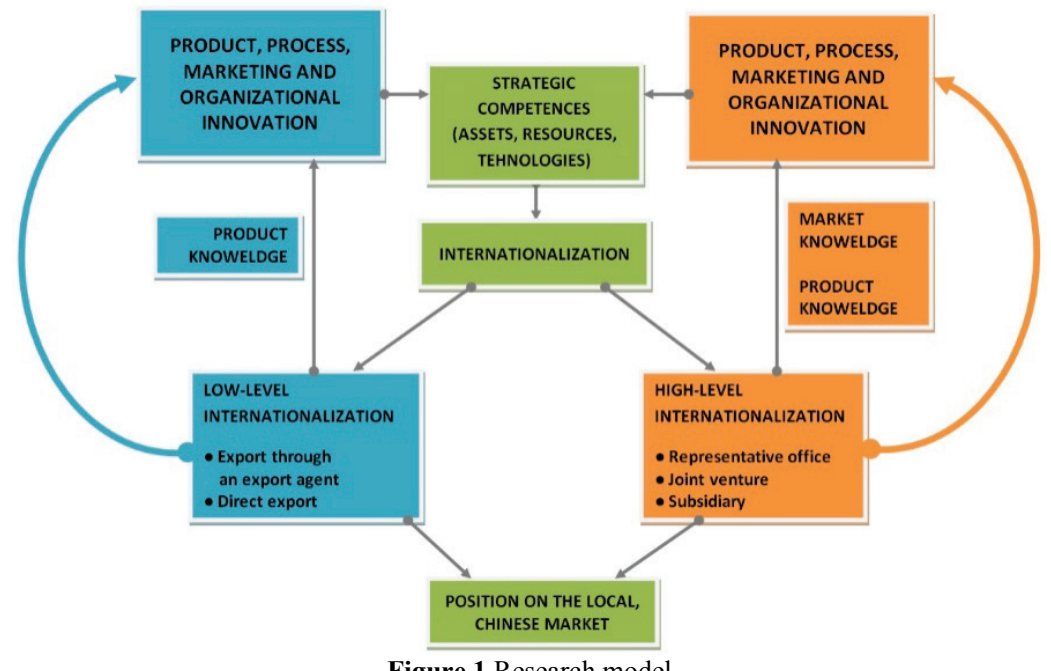

Figure 1 Research model

If a company chooses low-level internationalization, it can mostly gain access to product knowledge and that leads to the product innovation, process, marketing and organizational innovation. On the other side, if a company chooses high-level internationalization, it can gain access to both product and market knowledge and this might lead to more intensive product, process, organizational and marketing innovation. Again, all the innovation activities enhance company's strategic competences and probability that it becomes more involved in the internationalization activities and put more commitment into internationalization. This basically means that if company has more innovation activities that will help it to get access to more foreign markets, and once company is more successful on the international market, it will have more innovation activities. At the same time, the proposed research model suggests that all the international activities will help company to improve its position on the local, Chinese market. 


\section{Results of research - Innovation in Chinese companies with internationalization when direct export is considered as the high-level internationalization stage}

In order to achieve better understanding of the data analyzed, Chinese companies with internationalization are separated into the ones that have low-level internationalization and the ones with high-level internationalization. For the purpose of this paper, we are presenting results where direct export is considered as the high-level internationalization stage.

Table 1 Results of $t$-test and Levene's test for the differences in four types of innovation after internationalization between Chinese companies with lowlevel and high-level of internationalization (where direct export is included in high-level internationalization)

\begin{tabular}{|c|c|c|c|c|c|}
\hline \multicolumn{2}{|c|}{} & $\begin{array}{c}\text { Levene's test for equality of } \\
\text { variances }\end{array}$ & \multicolumn{2}{c|}{$t$-test for independent samples } & $t$ \\
\cline { 3 - 6 } & & $F$ & $P f$ & $P(2$-tailed) \\
\hline Product innovation & $\begin{array}{c}\text { Equal variances not } \\
\text { assumed }\end{array}$ & 4,521 & 0,034 & 1,748 \\
\hline Process innovation & Equal variances assumed & 0,531 & 0,467 & 2,651 & 2,063 \\
\hline Marketing innovation & Equal variances assumed & 0,099 & 0,753 & 2,790 & 285 \\
\hline Organizational innovation & Equal variances assumed & 2,115 & 0,147 & 2,752 & 285 \\
\hline
\end{tabular}

The following Tab. 1 shows the differences between Chinese companies, when it comes to the specific four types of innovation that are important for this survey.

According to the results of this test presented in the previous table, there are highly significant differences between respondents from the two groups of companies when it comes to process innovation $(t=2,651, p<0,01)$, marketing innovation $(t=2,790, p<0,01)$ and organizational innovation $(t=2,752, p<0,01)$ after their companies started doing business outside of China. When it comes to product innovation, there is a marginal significant difference $(t=1,748, p<0,1)$. Respondents from Chinese companies with high-level of internationalization evaluate the degree of process innovation (means is 3,89), marketing innovation (means is 3,84 ) and organizational innovation (means is 3,71 ) in their companies after internationalization more positive than respondents from low-level internationalized Chinese companies (means are 3,44, 3,36 and 3,22 respectively). Respondents from Chinese companies with high-level internationalization also evaluated the degree of product innovation more positive (means is 4,02 ) than companies with low-level internationalization (means is $3,67)$.

In addition to everything previously mentioned, there is significant difference between two groups of companies in the way they see innovation in fostering internationalization $(t=2,239, p<0,05)$. Respondents from the highly-internationalized Chinese companies reported the relationship about being more innovative and more chance to find international partners more positively.

\section{Conclusion}

The central task of this paper is to prove that the proposed research model based on Uppsala internationalization theory $[11,12]$ is sustainable for this type of research.

At the same time, internationalization is proved to exist not just in order to help companies achieve higher revenues, but in order to access the knowledge that company can use to innovate. In this framework, internationalization should be considered as a strategically important action for company to become more innovative and more competitive, both on the local and international markets.

It was definitely proved that there is a very strong linkage between Chinese companies internationalization efforts, and positive influence on their innovation. Relationship between innovation and internationalization in Chinese companies with low-level and high-level internationalization was tested and it was proved that all four types, product, process, marketing and organizational innovations were positively influenced by high-level internationalization. For the purpose of this paper, direct export was considered as high-level internationalization and the results have indicated that direct contact with foreign customers is extremely important for having higher benefits of internationalization in the context of improvement of all four types of innovation. Direct export itself was proved to allow Chinese companies to better absorb product knowledge and to get access to certain level of market knowledge outside the country's borders, in this case without making cross border investments. This research results go in line with Salomon and Shaver [36] who found out that knowledge that comes to the company by exports only consequently promotes innovation in all aspects of their business operation.

Major limitation for this research has been the fact that most of the companies surveyed are located in several Chinese provinces and the results should be understood in this framework. However, the number of collected respondents was high enough to be considered as valid and representative. Further research on this topic should involve companies from other regions of China and even companies from some other emerging markets that would be interesting to compare and additionally prove the research model. Also, it is suggested that further research contains larger number of separated analyses for manufacturing and service sectors and for different industries.

\section{References}

[1] Porter, M. The Competitive Advantage of Nations. Free Press, New York, 1990. DOI: 10.1007/978-1-349-11336-1

[2] Afuah, A. Innovation Management, Strategies, Implementations and Profits, 2nd Ed. Oxford University Press, Oxford, 2003 
[3] OECD. Guidelines for collecting and interpreting innovation data. 3rd. Ed. Oslo Manual, Paris, 2005. URL http://www.oecd-ilibrary.org/science-and-technology/oslomanual 9789264013100-en

[4] Yip, G.; McKern, B. Innovation in emerging markets - the case of China. // International Journal of Emerging Markets. 9, 1 (2014). pp. 2-10. DOI: 10.1108//JoEM-11-20130182

[5] Temple, R. The Genius of China: 3,000 Years of Science, Discovery and Invention. Inner Traditions, 2007.

[6] Tan, Y. Chinnovation. John Wiley \& Sons (Asia) Pte. Ltd., Singapore, 2011.

[7] Govindarajan, V.; Trimble, C. (2012) Reverse Innovation. Harvard Business Review Press, Boston, Massachusetts, 2012.

[8] Innovation by Chinese EMNSs, Chapter 4 // The Competitive Advantage of Emerging Market Multinationals / Williamson, P. J.; Yin, E. Cambridge: Cambridge University Press, 2013. pp. 64-80.

[9] Wagner, K.; Taylor, A.; Zablit, H.; Foo, E. The most innovative companies 2014. Boston Consulting Group (BCG), Boston, 2014.

[10] Hitt, M. A.; Hoskisson, R. E.; Ireland, R.D. A mid-range theory of the interactive effects of international and product diversification on innovation and performance. // Journal of Management. 20, (1994). pp. 297-326. DOl: 10.1177/014920639402000203

[11] Johanson, J.; Vahlne, J. The Internationalization process of the firm: a model of knowledge development and increasing foreign market commitment. // Journal of International Business Studies. 8, 1(1977), pp. 23-32. DOl: 10.1057/palgrave.jibs. 8490676

[12] Johanson, J.; Vahlne, J. The mechanism of internationalization. // International Marketing Review. 7, 4(1990), pp. 11-24. DOI: 10.1108/02651339010137414

[13] Zhang, S. International Trade Theory and Practice. 2nd. Ed. University of International Business Economic Press, Beijing, 2011.

[14] Tsai, H.-T., Eisingerich, A. Internationalization Strategies of Emerging Markets Firms. // California Management Review. 53, 1(2010), pp. 114-135. DOl: 10.1525/cmr.2010.53.1.114

[15] Crick, D.; Crick, J. The internationalization strategies of rapidly internationalizing high-tech UK SMEs. // European Business Review. 26, 5(2014), pp. 421-448. DOl: 10.1108/EBR-12-2012-0073

[16] Inzelt, A. Innovation and internationalization in the world of the small. // Warsaw Scholl of Economics, Collegium of World Economy, World Economy Research Institute, Warsaw, 2013.

[17] Peng, M. W. Perspectives - from China strategy to global strategy. // Asia Pacific Journal of Management. 22, (2005), pp. 123-141. DOI: $10.1007 /$ s10490-005-1251-3

[18] Mathews, J. A. Competitive advantages of the latecomer firm: A Resource-based account of industrial catch-up strategies. // Asia Pacific Journal of Management. 19, (2002), pp. 467-488. DOI: 10.1023/A:1020586223665

[19] Chan, T.; Michael, D.C.; Nettesheim, C.; Tong, M.; Tratz, A. End of easy growth-fast growing companies face headwinds as they expand. The 2012 BCG 50 Chinese Global Challengers, Boston, 2012.

[20] Kumar, V.; Mudambi,R.; Gray, S. Internationalization, innovation and institutions: the 3 I's underpinning the competitiveness of emerging market firms. // Journal of International Management. 19, 3(2013), pp. 203-206. DOI: 10.1016/j.intman.2013.03.005

[21] Li, C.; Zhou, Y. Driver to the formation of INV: The case of four Zhejiang SMEs. // Journal of Management Case Studies. 2, (2009), pp. 180-193.
[22] Backaler, J. China Goes West: Everything You Need to Know about Chinese Companies Going Global. Palgrave Macmillan, 2014. DOI: 10.1007/978-1-137-29393-0

[23] Zeng, M.; Williamson, P. J. Dragons at your door. How Chinese Cost innovation Is Disrupting Global Competition. Harvard Business School Publishing Corporation, 2007.

[24] Caves, R. E. Multinational Enterprise and Economic Analysis. Cambridge University Press, Cambridge, 1982.

[25] Kotabe, M. The relationship between offshore sourcing and innovativeness of US multinational firms: An empirical investigation. // Journal of International Business Studies. 21, 4(1990), pp. 623-638. DOI: 10.1057/palgrave.jibs.8490344

[26] Hitt, M.; Hoskisson, R.; Kim, H. International diversification: Effects on innovation and firm performance in product-diversified firms. // Academy of Management Journal. 40, 4(1997), pp. 767-798. DOI: 10.2307/256948

[27] Zahra, S. A.; Ireland, R. D.; Hitt, M. A. International expansion by new venture firms: International diversity, mode of market entry, technological learning and performance. // Academy of Management Journal. 43, 5(2000), pp. 925-950. DOl: 10.2307/1556420

[28] Filipescu, D. Innovation and Internationalisation. A Focus on Spanish Exporting Firms. Universitat Autonoma de Barcelona, Barcelona, 2007.

[29] Kafouros, M. I.; Buckeley, P. J.; Sharp, J. A. The role of internationalization in explaining innovation performance. // Technovation. 28, 1-2(2008), pp. 63-74. DOI: 10.1016/j.technovation.2007.07.009

[30] Cassiman, B. E.; Golovko, E. Innovation and internationalization through exports. // Journal of International Business Studies. 42, 1(2011), pp. 56-75. DOI: 10.1057/jibs.2010.36

[31] Wakelin, K. Innovation and export behaviour at the firm level. // Research Policy. 26, 7-8(1998), pp. 829-841. DOI: 10.1016/s0048-7333(97)00051-6

[32] Molero, J. Patterns of internationalisation of Spanish innovatory firms. // Research Policy. 27, 5(1998), pp. 541558. DOI: $10.1016 / S 0048-7333(98) 00064-X$

[33] Pavitt, K. Patent statistics as indicators of innovative activities: Possibilities and problems. // Scientometric. 7, 12(1985), pp. 77-99.

[34] Archibugi, D.; Piant, M. Measuring technological change through patents and innovation surveys. // Technovation. 16, 9(1996), pp. 451-467. DOI: 10.1016/0166-4972(96)00031-4

[35] Measuring innovation // Handbook of Innovation / Smith, K. H. Oxford: Oxford University Press, 2005, pp. 148-177.

[36] Salomon, R. M.; Shaver, J. M. Learning by exporting: New insights from examining firm innovation. // Journal of Economics \& Management Strategy. 14, (2005), pp. 431460. DOI: 10.1111/j.1530-9134.2005.00047.x

[37] Tang, M.; Li, M.; Zhang, T. The impacts of organizational culture on information security culture: a case study. // Information Technology and Management. 7, 2(2016), pp. 179-186. DOI: 10.1007/s10799-015-0252-22

[38] World Trade Organization (WTO), International trade statistics 2015. https://www.wto.org/english/res_e/statis_e/ its2015_e/its2015_e.pdf (27.12.2016)

[39] Vernon, R. International Investment and International Trade in the Product Cycle. // The Quarterly Journal of Economics. 80, 2(1966), pp. 190-207. DOI: 10.2307/1880689 


\section{Authors' addresses}

Nikola Zivlak, PhD, Assist. Prof.

Center of International Programs, Donghua University 1882 West Yan'an Road, Shanghai, 200051, China zivlak@gmail.com

\section{Marko Ljubičić, PhD}

Center of International Programs, Donghua University 1882 West Yan'an Road, Shanghai, 200051, China mr.ljubicic@gmail.com

\section{Ming Xu, PhD, Full Prof.}

Glorious Sun School of Business and Management, Donghua University

1882 West Yan'an Road, Shanghai, 200051, China xuming@dhu.edu.cn

Jelena Demko-Rihter, PhD, Assist. Prof.

University of Novi Sad,

Faculty of Technical Sciences

Trg Dositeja Obradovića 6, 21000 Novi Sad, Serbia jciric@uns.ac.rs

\section{Bojan Lalić, PhD, Associate Prof.}

University of Novi Sad,

Faculty of Technical Sciences

Trg Dositeja Obradovića 6, 21000 Novi Sad, Serbia

blalic@uns.ac.rs 